\title{
Matija Frkić o intelektu i besmrtnosti duše*
}

\author{
IVANA SKUHALA KARASMAN \\ Institut za filozofiju, Zagreb \\ ivana@ifzg.hr
}

UDK 1Frkić, M.

1(091)(497.5)"14/16"

141.132

Pregledni rad

Primljen: 26. 5. 2021.

Prihvaćen: 15.6 .2021$.

https://doi.org/10.52685/pihfb.47.1(93).3

\begin{abstract}
Sažetak
U središtu ovog članku nalazi se Frkićevo razumijevanje intelekta i besmrtnosti duše o kojima piše u svom djelu Vestigationes peripateticae de quibusdam philosophicis ad mentem Aristotelis (Peripatetička istraživanja o nekim filozofskim problemima u duhu Aristotela) koje je objavljeno 1639. godine u Padovi. Početna pozicija koja se može pratiti kroz cijelu argumentaciju koju izvodi svodi se na sljedeće: Frkić je svjestan kako u Aristotelovim tekstovima ne postoji konkretno mjesto na temelju kojega se može konstatirati kako sam Aristotel smatra dušu besmrtnom, stoga je potrebno provesti interpretaciju cjelovitog Aristotelovog opusa koja bi dopuštala mogućnost besmrtnosti jednog dijela duše. Frkić se u drugoj knjizi Šestog istraživanja Peripatetičkih istraživanja bavi problemom razumske duše. On, u skladu s kršćanskim naukom, smatra kako je ljudska razumska duša besmrtna. Ona se još naziva razum ili duhom i odvojiva je od tijela. Njezino djelovanje ne ovisi o tijelu, prema tome ona može samostalno opstojati.
\end{abstract}

Ključne riječi: Matija Frkić, besmrtnost duše, intelekt, peripatetička filozofija

\section{Uvod}

Hrvatski filozof, teolog i franjevac konventualac ${ }^{1}$ Matija Frkić ili Frće, Ferkić (lat. Matthaeus Ferchius Veglensis) rođen je na otoku Krku 24. siječnja 1583. godine. ${ }^{2}$ Studirao je u skladu s ondašnjim školskim kurikulumom filozofiju

\footnotetext{
* Ovaj rad u cijelosti je financirala Hrvatska zaklada za znanost projektom IP-2018-01-4966.

${ }^{1}$ Red je osnovan 1517. godine kad je papa podijelio franjevački red na opservante i konventualce.

${ }^{2}$ O Matiji Frkiću su u Hrvatskoj još pisali Joso Milošević, Mato Polonio, Karlo Balić, Mirko Dražen Grmek, Ivan Golub, Mihaela Girardi- Karšulin i Ljerka Schiffler.
} 
i teologiju u Bergamu, Padovi i Rimu. U Bergamu je doktorirao teologiju 1611. godine. Zahvaljujući tome što je bio regens studiorum ${ }^{3}$, boravio je u Veneciji, Riminiju i Bologni. Kako je bio franjevac konventualac, za potrebe reda putovao je Europom. Na Sveučilištu u Padovi ${ }^{4}$ 1628. godine imenovan je profesorom metafizike in via Scoti, a dvije godine kasnije postaje profesor teologije:

»Kao javni predavač za skolastičku metafiziku, Frkić na filozofskom i teološkome padovanskome kolegiju svoje učenje zasniva u općem znaku proučavanja i tumačenja Aristotelova autoriteta, posebice u klimi i kontroverzi i odbijanja središnjih kozmoloških, psiholoških i gnoseoloških rješenja Aristotelove filozofije. $\ll^{5}$

Bio je i gvardijan na Krku i provincijal Reda. Polemizirao je s franjevcima Bartolomejom Mastrijem (1602 - 1673), Bonaventurom Beluttijem (1599 1679) te filozofom i liječnikom Fortunom Licetijem (1577 - 1657). U Padovi je 1636. godine osnovao knjižnicu za profesore teologije kojoj je donirao sve svoje knjige. Frkić se je intenzivno bavio proučavanjem i preispitivanjem peripatetičke filozofije. Umro je u Padovi 8. rujna 1669. godine. Pokopan je u Bazilici Svetog Antuna Padovanskog. Ovako glasi epitaf na njegovu grobu:

\section{EPITAF MATIJI FRKIĆU}

koji se nalazi u bazilici sv. Antuna Padovanskog u Padovi

(Grob broj) CCXXXI (231)

Matija Frkić

$1669-1671$

(Natpis na pilastru...)

Posjetitelju, ovo je lik mudra čovjeka, Matije Frkića, Krčanina, službenoga teologa reda Male braće konventualaca, koji je na padovanskom Liceju, premašujući sve oko sebe sjajnom slavom i učenošću, rasvjetljujući Scotova djela iz metafizike i sv. teologije tijekom 35 godina onoliko tajni odgonetnuo, koliko ih je ovaj zagonetnuo. Dospjevši do najviših stupnjeva časti i vrline, nakon što je nadmašio ostale, kao zaslužan je dopro među nebesnike u svojoj 88. godini, ljeta od utjelovljenja Gospodnjega 1669.

\footnotetext{
${ }^{3}$ Regens studiorum ekvivalent je današnjem položaju rektora nekog sveučilišta.

${ }^{4}$ Kao jednog od franjevca konventualca koji je predavao na Sveučilištu u Padovi navodi ga i Antonio Poppi u knjizi Ricerche sulla teologia e la scienza nella Scuola padovana del Cinque e Seicento (Soveria Mannelli: Rubbettino, 2001), p. 263.

${ }^{5}$ Ljerka Schiffler, Matthaeus Ferchius Veglensis, Mattheo Ferchio Veglense, Matja Frkić Krčanin 1583 - 1669 (Krk - Rijeka: Krčki zbornik - Verba d. o. o., 2010), p. 34.
} 
Ovaj mu spomenik vječna prijateljstva postavlja subrat Feliks Rotundus a Monte Leone, njegov nasljednik na teološkoj katedri, konzultor Sv. Oficija i generalni asistent Reda.

(Naknadno dodan natpis)

Doskora generalni ministar Reda, ljeta 1695, dana 21. svibnja.

(Niže)

Oci iz reda konventualaca dosada su predavali svetu teologiju in via Scoti 275, a metafiziku 200 godina u padovanskom Arhigimnaziju, vjero duhu roditelja najsjajnijih junaka.

$$
\text { Ljeta } 1671 .^{6}
$$

Frkić je kao što je vidljivo iz epitafa, koji je napisan dvije godine nakon njegove smrti, pokopan u Padovi na čijem je sveučilištu godinama predavao. U njemu se navode sve zasluge koje je tijekom života ostvario.

Svojim djelovanjem i životom Frkić je bio vezan uz Hrvatsku i Italiju. Ostavio je traga na obje kulture, kao što je Ljerka Schiffler zaključila:

»Premda su Frkićev život i djelo vezani uz talijansku, posebice padovansku kulturnu klimu, hrvatski je bogoslovac i filozof to više ostavio trag i u hrvatskoj povijesti mišljenja kako to svjedoče i hrvatski povjesničari kulture, filozofije i znanosti. Njegovo djelo s vremenom nije zastarjelo nego potiče na daljnja proučavanja još neiscrpnih segmenata, ostavljajući prostor mlađim naraštajima istraživača hrvatske filozofske baštine. $\ll^{7}$

Frkić je bio vrlo plodonosan pisac s više od petnaest knjiških naslova. U njima se priklanja skotističkoj interpretaciji Aristotelove filozofije. Zbog nesmanjenog interesa za Aristotelovu filozofiju, kao i njegove tumače, Frkićeva nam je filozofska misao još uvijek zanimljiva, kao što je to već napisala Mihaela Girardi-Karšulin:

»Ona zaslužuju našu pažnju ne samo zato što su u vrijeme kad su napisana i tiskana pobudila veliki interes i živu diskusiju, već i zato što je u 19. i 20. st. istraživanje Aristotelove filozofije jednako kao i istraživanje recepcije Aristotela-

${ }^{6}$ Epitaf je preveo Vicko Kapetanović. Preuzeto iz Ljerka Schiffler, Matthaeus Ferchius Veglensis, Mattheo Ferchio Veglense, Matja Frkić Krčanin 1583 - 1669, p. 15.

${ }^{7}$ Ljeka Schiffler, Matthaeus Ferchius Veglensis, Mattheo Ferchio Veglense, Matija Frkić Krčanin 1583 - 1669, p. 25. 
istraživanje utjecaja aristotelizma kroz stoljeća evropske kulturne povijesti, dobilo nove poticaje i angažiralo poznate i značajne istraživače povijesti filozofije« ${ }^{8}$

Njegovo glavno djelo Vestigationes peripateticae de quibusdam philosophicis ad mentem Aristotelis (Peripatetička istraživanja o nekim filozofskim problemima u duhu Aristotela) objavljeno je 1639. godine u Padovi. U njemu Frkić polemički analizira prijepore teologije i peripatetičke filozofije. Djelo je doživjelo ozbiljne kritike te 1655 . godine i crkvenu osudu zbog kršenja dogme o Božjem stvaranju. Frkić svojim kritičarima odgovara djelom Defensio Vestigationum peripateticarum ab offensionibus Belluti et Mastrii (Obrana peripatetičkih istraživanja od uvreda Bellutija i Mastrija) koje je objavljeno 1646. godine. Na samom početku knjige umeće potvrdu kojom se izjavljuje da je djelo napisano u skladu s učenjima Katoličke crkve. U toj se potvrdi dozvoljava tiskanje Frkićeve knjige, a potpsuje je Pietro Foscarini. Pietro Foscarini imao je funkciju »riformatore dello studio di Padova«, t. j. bio je službenik Mletačke republike za nadzor nad obrazovanje, pogotovo Padovanskog sveučilišta. U potvrdi piše:

»Mi državni padovanski reformatori, pošto smo vidjeli po vjeri časnog oca padovanskog inkvizitora da se u knjizi naslovljenoj Obrana peripatetičkih istraživanja Matije Frkića Krčanina, teologa na Padovanskom sveučilištu ne nalazi nikakva stvar protivna svetoj katoličkoj vjeri i jednako se ne nalazi nijedna stvar protiv principa i dobrih običaja, dajemo dozvolu da se tiska $<\ldots>$..119

Ovom Obranom Frkić želi postići dva cilja: napisati u crkvenim krugovima prihvaćeno djelo o peripatetičkoj filozofiji i obraniti se od oštrih napada subraće Bellutija i Mastrija.

U svoje tri Apologije objavljene 1619. i 1620. godine te u djelima Vita objavljenom 1622. godine i u Discussiones Scoticae objavljenom 1638. godine izložio je život i djelo filozofa i teologa Ivana Dunsa Škota (oko 1266-1308). Frkić je autor djela iz prirodne filozofije De caelesti substantia et eius ortu ac motu in sententia Anaxagorae philosophi celeberrimi (O supstanciji neba i o njezinu nastanku i kretanju po učenju Anaksagore, vrlo slavnog filozofa) koje je objavljeno u Veneciji 1646. godine.

U središtu ovog članka nalazi se Frkićevo učenje o intelektu i besmrtnosti duše. Radi potpunije kontekstualizacije Frkićeva pristupa tom problemu prvo donosim pregled osnovnih problema na koje se nailazi u Frkićevim djelima, a koja su napisana u peripatetičkom duhu. Frkićev se interes za problem be-

\footnotetext{
${ }^{8}$ Mihaela Girardi-Karšulin, Hrvatski renesansni aristotelizam, $»$ Dva osnovna peripatetička problema u djelu Matije Frkića« (Zagreb: Hrvatsko filozofsko društvo, 1993), pp. 169-208, na p. 169.

${ }^{9}$ Mattheus Ferchius, Defensio Vestigationum peripateticarum ab offensionibus Belluti et Mastrii (Paduae: Io. Baptista Pasquati, 1646), [s. p.].
} 
smrtnosti duše može promatrati u kontekstu nastavka prisutnosti peripatetičke filozofije kao prevladavajućeg filozofskog smjera na talijanskim sveučilištima i za vrijeme renesanse, te na temelju toga potrebe da se propitaju neki otvoreni problemi i pitanja nepodudaranja peripatetičkog stava s dominantnom doktrinom katoličke crkve. Besmrtnost duše jedna je od tema u svezi s kojom postoji nesklad između Aristotelove filozofije i učenja Katoličke crkve.

Ovdje treba napomenuti kako je u renesansi sastavljeno $»<\ldots>$ više komentara na corpus Aristotelicum od ikojeg drugog razdoblja (pritom nema baš oštre crte razgraničenja između komentara, udžbenika, enciklopedija, članaka itd.). $\ll^{10}$ Od hrvatskih filozofa komentare na Aristotelova djela pišu Antun Medo (1530 - 1603) i Juraj Dubrovčanin (druga polovica 16. st. - 1622) da spomenem samo neke.

Premda se mnogo piše o renesansnim kritikama Aristotela, ne treba smetnuti s uma da tad uopće nije janjavao interes za komentiranjem filozofije Aristotela i njegovih skolastičkih sljedbenika te usklađivanje Aristotelova nauka s kršćanskim u nekim pitanjima kao što je to nastanak svijeta i besmrtnost duše. ${ }^{11}$ Stoga nije neobično što je svoje filozofsko promišljanje Frkić posvetio Škotovoj filozofiji.

\section{Temeljni problemi Frkićevih djela}

Najznačajnije Frkićevo filozofsko djelo su Peripatetička istraživanja ${ }^{12}$ (Vestigationes peripateticae) objavljeno 1639. godine u Padovi. Djelo sadrži deset istraživanja:

1. »O tvorbi iz ničega« / »De factione ex nihilo«

2. »O tvornosti prvoga bića / »De efficientia primi entis «

3. »O načinu tvorenja prvoga bića« / »De modo efficiendi primi entis«

4. »O jedinstvu Boga / »De unitate Dei«

5. »O broju nebesa / »De caelorum numero«

6. »O odvojenoj formi $/ »$ De forma separabili«

7. »O broju kategorija / »De numero praedicamentorum«

8. »O spoznatljivom za čovjeka« / »De cognoscibilibus ab homine«

9. »O trostrukoj podjeli znanosti«/ /De scientiarium divisione tripartita 10. »O prvom spoznatom $\ll / »$ De primo cognito

${ }^{10}$ Luka Boršić, Renesansne polemike s Aristotelom. Nizolio-Petrić-Mazzoni (Zagreb: KruZak, 2013), p. 24.

${ }^{11}$ Više o novim tumačenjima Aristotela koji se javljaju u renesansi vidi: Brian P. Copenhaver, Charles B. Schmitt, Renaissance Philosophy (Oxford - New York: Oxford University Press, 1991), p. 62 i dalje.

${ }^{12}$ Matthaeus Ferrchius, Vestigationes peripateticae de quibusdam philosophicis ad mentem Aristotelis (Patavii: Trambotti, 1639). 
Kao što je već rečeno, u središtu Frkićeva djela nalaze se problemi koji su u njegovo vrijeme bili predmetom polemika i rasprava u peripatetičkoj filozofiji. Ova se Frkićeva nastojanja mogu promatrati u kontekstu promjena koje se događaju u renesansnom aristotelizmu a koje neki autori dovode $\mathrm{u}$ vezu s pojavom novovjekovne znanosti. ${ }^{13}$ Neću ići tako daleko i tvrditi kako je Frkić neposredno sudionik koji je presudan za povezivanje renesansnog aristotelizma s počecima suvremene znanosti, no njegova se nastojanja oko revizije interpretacije Aristotelove prirodne filozofije mogu shvatiti kao dio opće tendencije koja je dovela do tog povezivanja.

Ovo prvo istraživanje O tvorbi iz ničega « predstavlja njegov inauguralni nastup kao profesor metafizike na Sveučilištu u Padovi. To je ujedno i najoriginalniji dio Frkićevih Peripatetičkih istraživanja. ${ }^{14}$ Ovdje Frkić želi dokazati da se tezu »iz ničega ništa ne nastaje « ne može pripisati Aristotelu i da ona nije u skladu s peripatetičkom filozofijom. Revidiranjem Aristotelova objašnjenja stvaranja ni iz čega, Aristotelova bi se filozofija mogla uskladiti s kršćanskim viđenjem svijeta, kao što piše Mihaela Girardi-Karšulin:

»Dokazati da Aristotel nije tvrdio tezu: iz ničega ništa ne nastaje, za Frkića prije svega znači dokazati da je Aristotelova filozofija primjerena kršćanskoj vjeri, da je u stanju spoznati svijet kao stvoren (učinjen) i ujedno spoznati Boga kao transcendentnog stvaraoca, metafizički, transcendentni tvorni princip svijeta. Direktne potvrde u Aristotelovu tekstu za svoju tezu da je Aristotel poznavao i priznavao metafizički - transcendentni uzrok i tvorenje iz ničega, Frkić svakako ne može navesti, pa to i priznaje. On nastoji, međutim, protumačiti sporna mjesta (vječnost materije, forme, kretanja, svijeta) tako da ne dođu u sukob s tezom: iz ničega ništa ne nastaje. $\ll^{15}$

Ovdje Mihaela Girardi-Karšulin ukazuje kako sam Frkić ne može navesti mjesto u Aristotelovu tekstu koje bi pokazalo kako je moguće kod njega pronaći stvaranje iz ničega. Umjesto toga Frkić interpretira vječnost materije, forme kretanja i svijeta kao zakone svijeta, dakle zakone koji vrijede nakon nastanka svijeta. Ti sami zakoni time više nisu u suprotnosti s kršćanskim konceptom stvaranja iz ničega, jer se odnose na stvoreni svijet i ne govore ništa o samom stvaranju.

Drugo Frkićevo značajno djelo jest Defensio Vestigationum peripateticarum ab offensionibus Belluti et Mastrii ${ }^{16}$ (Obrana peripatetičkih rasprava od

${ }^{13}$ Vidi: Luka Boršić, Renesansne polemike s Aristotelom. Nizolio - Petrić - Mazzoni.

${ }^{14}$ Vidi: Mihaela Girardi-Karšulin, Hrvatski renesansni aristotelizam, »Dva osnovna peripatetička problema u djelu Matije Frkića«, p. 172.

${ }^{15}$ Mihaela Girardi-Karšulin, Hrvatski renesansni aristotelizam, $»$ Dva osnovna peripatetička problema u djelu Matije Frkića«, p. $172-173$.

${ }^{16}$ Matthaeus Ferrchius, Defensio Vestigationum peripateticarum ab offensionibus Belluti et Mastrii (Patavii: Jo. Baptista Pasquali, 1646). 
napada Beluttija i Mastrija) objavljeno 1646. godine u Padovi. Za objavu ovo je djelo pripremio Frkićev učenik Iacobus Georgius, a posvetio ga je franjevcu konventualcu Petru Rusci koji je bio generalni namjesnik Svete inkvizicije u Padovanskoj biskupiji. U ovoj knjizi Frkić se nastoji obraniti od kritike Beluttija i Mastrija, ali ujedno i dodatno objasniti teze koje je iznio u prvom i šestom istraživanju. Ovo djelo, kako navodi Girardi-Karšulin, ima polemički karakter $»<\ldots>$ jer predstavlja odgovor i obranu protiv objekcija, napada i 'uvreda' koje su Belluti i Mastrio - također franjevci - objavili u knjizi O rađanju i propadanju (De generatione et coruptione Disp. V. q. I, Venetiis 1640.) kao kritiku Frkićeve knjige Peripatetička istraživanja. ${ }^{17}$ Djelo uz »Prolog « ima četiri knjige i dva korolarija »Otkrivena kradljivost Beluttija i Mastrija« (»Furacitas Belluti et Mastrii patefacta $)$ i »Okrutnost Beluttija i Mastrija« (»Feracitas Belluti et Mastrii«).

Treća značajna Frkićeva knjiga je De caelesti substantia et eius ortu ac motu in sententia Anaxagorae philosophi celeberrimi ( $O$ supstanciji neba $i$ o njezinu nastanku i kretanju po učenju Anaksagore, vrlo slavnog filozofa) objavljena u Veneciji 1646. godine, a posvećena je Aloisu Mustiu. Posvetu je napisao Pietro Rusca. Knjiga je podijeljena na sljedeće dijelove: prvo Frkić donosi Anaksagorin životopis, zatim dolaze poglavlja »O nebeskoj supstanciji« (»De caelesti substantia $)$, »O nastanku neba« (»De caeli ortu«), »O suprotnosti u nebeskom kretanju« (»De caelestis motus contrarietate «), »O složenosti nebeskog kretanja« (»De caelestis motus compositione) « $\mathrm{i} » P r i l o g «$ (»Appendix ad librum primum de caelesti substantia«). U ovom djelu Frkić se ponovno bavi pitanjima koja je otvorio u svojim prethodnim djelima, a koja se odnose na usklađenje aristotelovske prirodne filozofije s kršćanskim učenjem. Tako se dotiče pitanja nastanka i vječnosti neba, jednog od temeljnih razlika aristotelovskog i kršćanskog prirodnofilozofskog pristupa. Središnje pitanje o kojem Frkić raspravlja u ovom djelu jest $»<\ldots>$ pitanje da li su četiri navedena elementa ujedno i svi elementi iz kojih su sastavljena prirodna tijela ili ima i takvih prirodnih tijela za koje se mora pretpostaviti da su građena iz nekih drugih elemenata. ${ }^{18}$ On odbacuje nauk o petoj supstanciji (eteru) i također odbacuje Aristotelovo učenje o vječnosti neba.

Četvrta knjiga koju ovdje treba spomenuti jest Recognitio peripatetica Aristotelis ut magistri, Liceti ut discipuli, an omnium Aristotelicorum celeberrimi? (Peripatetičko razmatranje o tome jesu li Aristotel kao učitelj i Liceti kao učenik najslavniji među svim aristoteličarima?). Ona je objavljena također u

\footnotetext{
${ }^{17}$ Mihaela Girardi-Karšulin, Hrvatski renesansni aristotelizam, »Dva osnovna peripatetička problema u djelu Matije Frkića«, p. 193.

${ }^{18}$ Mihaela Girardi-Karšulin, Hrvatski renesansni aristotelizam, »Problem jedinstva sublunarnog i supralunarnog svijeta u knjizi: O nebeskoj supstanciji, Matije Frkića«, p. 83.
} 
Padovi 1656. godine. Kao i njegovo djelo Obrana peripatetičkih rasprava od napada Beluttija i Mastrija i ovo djelo polemičkog je karaktera u kojem Frkić kritizira tada poznatog peripatetičara Licetija.

Frkić je autor i djela o Torquatu Tassu Osservationi sopra il Goffredo del Signor Torquato Tasso (Razmatranja o Goffredu Torquata Tassa) ${ }^{19}$ objavljenog u Padovi 1642. godine.

Mihaela Girardi-Karšulin navodi još dva Frkićeva djela, a to su Oratio praeludialis ad metaphysicam et alia similis ad theologiam (Uvodni govor za metafiziku i drugi sličan za teologiju), objavljeno u Padovi 1634. godine. Ne zna se gdje se nalazi primjerak te knjige. Druga navedena Frkićeva knjiga jest Quaestiones tres ad logicae proemium de necessitate secundarum intentionum et de logica docente ac utente, utrum sit scientia (Tri kvestije za uvod u logiku, o nužnosti sekundarnih pojmova i o tome je li normativna i primijenjena logika znanost). Nju navodi Joso Milošević ${ }^{20}$ iako je nikad nije vidio. ${ }^{21}$

Valja zaključiti da »[i] mnoga druga djela i spisi koje je Frkić objavio ili su ostala u rukopisu ili su zagubljena i do danas ostala poznata samo naslovom, kazuju o mnogostranome njegovu zanimanju i erudiciji u različitim područjima filozofije, odnosno teologije (povijesti, prirodne filozofije, mariološke tematike, moralno etičke, književna i druga djela). $\ll^{22}$

Frkićev filozofski opus je bio u potpunosti vezan uz aristotelovsku filozofiju, prije svega prirodnu filozofiju. Povezanost uz aristotelovsku prirodnu filozofiju tipična je za akademske situacije sjevernotalijanskih sveučilišta njegova vremena. Kako piše Paul Oskar Kristeller u tekstu »Renaissance Aristotelianism«, aristotelizam je u renesansi nastavak tradicije, koja se zadržala $\mathrm{u}$ akademskim krugovima kao dio službenog kurikuluma. ${ }^{23}$

Frkićevo djelovanje i spise treba promatrati u sklopu renesansnih previranja i rješavanja, s jedne strane, odnosa prema antičkoj filozofskoj tradiciji,

${ }^{19}$ Više o ovom djelu vidi u: Ljerka Schiffler, »Matija Frkić tumač i kritičar Tassa: Osservationi sopra il goffredo del signor Tourquato Tasso«, Prilozi za istraživanje hrvatske filozofske baštine 21/1-2(41-42) (1995), pp. 83-108.

${ }^{20}$ Za bibliografiju Matije Frkića vidi: Joso Milošević, Život i djelo fra Mate Ferkića iz Krka, Rad JAZU, br. 164 (1906); Ljerka Schiffler, Matthaeus Ferchius Veglensis, Mattheo Ferchio Veglenese, Matija Frkić Krčanin 1583 - 1669 (Krk - Rijeka: Povjesno društvo o. Krka - Krčki zbornik, sv. 66 - Posebno izdanje sv. 61 - Povijesno društvo Rijeka - Verba d. o. o. Rijeka, 2010), pp. $104-105$.

${ }^{21}$ Vidi: Mihaela Girardi-Karšulin, Hrvatski renesansni aristotelizam, »Dva osnovna peripatetička problema u djelu Matije Frkića«, p. 170.

${ }^{22}$ Ljerka Schiffler, Matthaeus Ferchius Veglensis, Mattheo Ferchio Veglenese, Matija Frkić Krčanin 1583-1669, p. 21.

${ }^{23}$ Vidi: Paul Oskar Kristeller, »Renaissance Aristotelianism«, Greek, Roman, and Byzantine studies VI (1965), pp. 157-174, na pp. 162-163. 
koja postaje ponovno prezentna i sveprisutna, i s druge strane usklađivanje te tradicije s dominantnom kršćanskom slikom svijeta. U kasnijim stoljećima će se razračunavanje s Aristotelom razumjeti kao razračunavanje sa skolastičkim viđenjem svijeta, no ovdje se još uvijek Aristotela i aristotelizam nastoji inkorporirati u kršćansku sliku svijeta. Neki od problema s kojima se Frkić pritom susreće, prestaju biti relevantni u kasnijem razdoblju i dobrim dijelom ispadaju iz područja interesa kasnijih filozofa (npr. problem supstancije neba). Time se ne umanjuje važnost tih problema za razdoblje u kojem je djelovao sam Frkić.

\section{O problemu intelekta i besmrtnosti duše}

Frkić nastavlja tradiciju bavljenja prirodnofilozofskim temama unutar renesansnog aristotelizma. Prema Kristelleru, platonizam se pokazao kao prihvatljivija filozofska pozicija kada se radi o etičkim i teološkim temama, no kada se radi o problemima kojima se bavi prirodna filozofija, platonizam se nije pokazao adekvatnom zamjenom postojećoj aristotelovskoj paradigmi i objašnjenjima. ${ }^{24}$ Nadalje, u knjizi Humanismus und Renaissance Kristeller navodi kako »<..> renesansni humanizam nije predstavljao po sebi nikakav novi pravac ili zatvoreni sistem unutar filozofije, već se prije svega radilo o kulturnom i obrazovnom programu $<\ldots>$ u kojem su u bitnome nije radilo ni o klasičnoj filologiji niti o filozofiji.« ${ }^{25}$

Paralelnost filozofskih i teoloških nauka, koja se odslikava u stavu koji je poznat kao nauk o dvije istine, objavljenoj i istini razuma, ovdje se pojavljuje kao okvir unutar kojega se Frkić bavi pitanjem ljudske duše i intelekta. Ovo su teme koje se tiču renesansnog razumijevanja čovjeka, ali jednako tako ih je moguće promišljati u kontekstu prirodnofilozofskih problema. Utoliko se javlja potreba i pokušaj za još jednim novim pogledom na sukladnost i uskladivost aristotelovskog prirodnofilozofskog razumijevanja duše, s kršćanskom vizijom duše. Ovaj Frkićev pokušaj nije jedinstven ni neuobičajen za kontekst u kojem se događa. Bavljenje besmrtnošću duše i intelektom u okviru aristotelovske tradicije bilo je prisutno gotovo pola stoljeća ranije u djelima Pietra Pomponazzija (1462 - 1525), koji svojom filozofijom pokušava odgovoriti na izazove koje postavlja neoplatonička tradicija i njihovo razumijevanje ljudske duše.

Problem besmrtnosti duše predstavlja jedno od središnjih pitanja kojima se bavi Frkić u svojim Peripatetičkim raspravama u kojima razvija interpretaciju Aristotelova razumijevanja duše koja bi bila uskladiva s kršćanskim vjerovanjem. Kao što je već pokazano prethodno u tekstu, ovaj problem je prisutan u

\footnotetext{
${ }^{24}$ Paul Oskar Kristeller, »Renaissance Aristotelianism«, p. 173.

${ }^{25}$ Paul Oskar Kristeller, Humanismus und Renaissance (München: Fink, 1974), p. 17.
} 
kontekstu prilagodbe skolastičkog aristotelizma koji se zadržao na sveučilištima novim interpretacijama koje otvara platonizam. Početna pozicija koja se može pratiti kroz cijelu argumentaciju koju izvodi Frkić mogla bi se svesti na sljedeće: Frkić je svjestan kako u Aristotelovim tekstovima ne postoji konkretno mjesto na temelju kojega se može konstatirati kako sam Aristotel smatra dušu besmrtnom, stoga je potrebno provesti interpretaciju cjelovitog Aristotelova opusa koja bi dopuštala mogućnost besmrtnosti jednog dijela duše. Polazna pozicija bila je prihvaćanje Aristotelova učenja o duši, prema kojemu je duša onaj dio koji je ključan za život, princip koji pruža i unosi život u materiju. ${ }^{26}$ Pri interpretaciji Aristotelove filozofije koja traži dokaze za uskladivost Aristotela s kršćanskom doktrinom o duši, Frkić »<..> svoju tezu obrazlaže i dokazuje suočavajući različite Aristotelove tekstove te tako dokazuje da teza o besmrtnosti ljudske razumske duše proizlazi iz Aristotelovih principa. $\ll^{27}$

Prema Frkiću, duša je odvojena forma i predstavlja predmet fizike, u podjeli područja i disciplina. Ovu podjelu temelji na razumijevanju duše kao onoga što je princip na temelju kojega biće postaje živo. Razumijevanje duše kao principa života prisutno je od antike i jedno je od razumijevanja duše. Sama duša dodatno se dijeli, jedan od dijelova razumski je i njega Frkić ne smatra dijelom fizičkog svijeta. Ako bi razumski dio duše (intelekt) bio predmetom fizike, sve bi razumske dijelove trebali smatrati dijelom fizike, što bi dovelo u pitanje postojanje metafizike kao samostalne znanosti. Dodatno se sam razum dijeli na dva dijela: aktivni i spekulativni dio. Ova podjela temelji se na odnosu razuma prema zamjedbi i predodžbi. Onaj dio duše koji se aktivno odnosi prema vanjskom svijetu, koji je povezan sa zamjedbom i predodžbom, naziva se aktivnim dijelom duše. Taj aktivni dio onaj je kojim se bavi fizika, dok je drugi dio onaj koji nije u fokusu fizike. Dakle, drugi dio je spekulativan i on ulazi u područje metafizike. Oba ova dijela duše, dijelovi su razumske ljudske duše, no:

»Razlikovanjem aktivnog i spekulativnog razuma, $<\ldots>$, želi se Frkić suprotstaviti aleksandrističkoj distinkciji duha (mens) koji pristupa izvana i razumske duše (anima inellectiva) koja je forma tijela. Po Aleksandru Afrodizijskom i njegovim sljedbenicima, jedino realno odvojiv jest Duh (Mens) koji je božanski-bog sam, dok je ljudska duša neodvojiva od materije - smrtna ${ }^{28}{ }^{28}$

${ }^{26}$ Aristotle, On the Soul, 402a5, u: The Complet Works of Aristotle, ed. Jonathan Barnes, vol. 1 (Princetone: Princeton University Press, 1995).

${ }^{27}$ Mihaela Girardi-Karšulin, Hrvatski renesansni aristotelizam, p. 186.

${ }^{28}$ Mihaela Girardi-Karšulin, Hrvatski renesansni aristotelizam, pp. 178-179. 
Frkić se u drugoj knjizi Šestog istraživanja bavi problemom razumske duše. On, u skladu s kršćanskim naukom, smatra kako je ljudska razumska duša besmrtna. Ona se još naziva razum ili duh i odvojiva je od tijela. Njezino djelovanje ne ovisi o tijelu, dakle ona može samostalno opstojati: »[t]vrdimo da razumska duša (koja se zbog svojeg najvišeg dijela, to jest uma češće naziva um ili intelekt) može postojati bez tijela jer djeluje bez tijela «. ${ }^{29}$ Duša je nadalje prvi akt tijela, ali i ona sama ima svoju zadaću. Kako duša ima svoju specifičnu zadaću, ona je odvojiva od tijela, no akt forme neodvojiv je od tijela. Razum (intelekt) odvojen je od tijela, jer razumu ne pripadaju ni kvalitativna ni osjetilna određenja. Frkić razlikuje između vlastite i zajedničke trpnje duše. Tako su trpnje vlastite duše poimanje i mišljenje, a zajedničke ljubav i spoznavanje. Postoje aktivni i pasivni razum koji su dvije razlike unutar razumske duše.

\section{Zaključak}

Frkićevo bavljenje temama određeno njegovom akademskom pozicijom i činjenicom da se peripatetička filozofija nalazi i dalje kao dominantna filozofska pozicija na talijanskim sveučilištima toga vremena, posebice na Padovanskom sveučilištu gdje je i sam predavao. Frkić ukazuje na to da se jednim specifičnim pristupom interpretaciji Aristotelove filozofije moguće približiti tadašnjem kršćanskom nauku o duši. Glavno je tu pitanje o besmrtnosti duše. Specifičnost Frkićeva pristupa $u$ interpretaciji sastoji se u nastojanju da se oni dijelovi problema besmrtnosti duše, o kojima se ne može dobiti jednoznačan odgovor neposredno iz Aristotelovih tekstova, sagledaju u kontekstu Aristotelova cjelovitog opusa komparativnom analizom i interpretacijom koja polazi s kršćanske pozicije. Frkić, polazeći s kršćanskih pozicija, smatra kako je razumska duša (intelekt) besmrtna.

\footnotetext{
${ }^{29}$ Matija Frkić, Peripatetička istraživanja, p. 286: »Animam intellectivam (quae a sua suprema parte, id est intellectu appellatur saepius intellectus, seu mens) quia sine corpore actionem habet, sine corpore esse posse asseveramus.«
} 


\section{VESTIGATIONES PERIPATETIC\& \\ Matthxi Ferchij Veglenfis Min: Conu: \\ In Vniuerfitate Patauina T heologi.}

ILLVSTRISSIMO, ET EXCELLENTISSIMO D.

D. I $\mathrm{O} A \mathrm{~A} N \mathrm{~N}$

BASADON NAE.

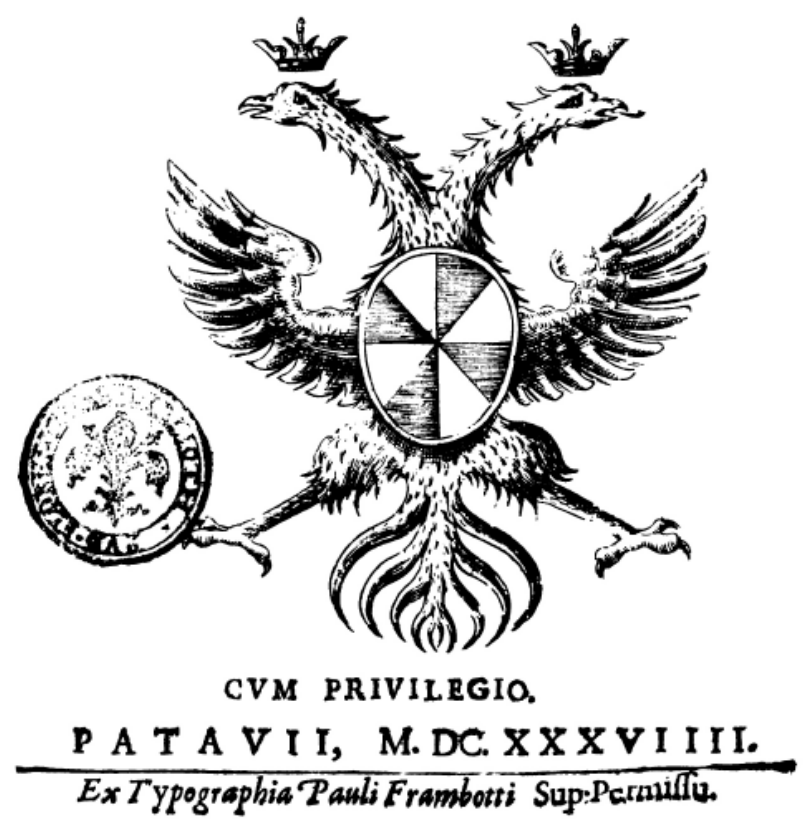

Slika 1. Naslovnica Peripatetičkih istraživanja, Padova, 1639. 


\section{Literatura}

Aristotle. 1995. On the Soul, 402a5, u: The Complet Works of Aristotle, ed. Jonathan Barnes, vol. 1 (Princetone: Princeton University Press).

Boršić, Luka. 2013. Renesansne polemike s Aristotelom. Nizolio-Petrić-Mazzoni (Zagreb: KruZak).

Copenhaver, Brian P., Schmitt, Charles B. 1991. Renaissance Philosophy (Oxford New York: Oxford University Press).

Ferrchius, Matthaeus, 1639. Vestigationes peripateticae de quibusdam philosophicis ad mentem Aristotelis (Patavii: Trambotti, 1639).

Ferrchius, Matthaeus. 1646. Defensio Vestigationum peripateticarum ab offensionibus Belluti et Mastrii (Patavii: Jo. Baptista Pasquali).

Ferrchius, Matthaeus, 1646. De caelesti substantia et eius ortu ac motu in sententia Anaxagorae philosophi celeberrimi (Venetiis: Apud Haeredes Ioannis Salis).

Girardi-Karšulin, Mihaela. 1993. Hrvatski renesansni aristotelizam, »Dva osnovna peripatetička problema u djelu Matije Frkića« (Zagreb: Hrvatsko filozofsko društvo).

Kristeller, Paul Oskar. 1965. »Renaissance Aristotelianism«, Greek, Roman, and Byzantine studies VI, pp. 157-174.

Kristeller, Paul Oskar.1974. Humanismus und Renaissance (München: Fink).

Milošević, Joso. 1906. Život i djelo fra Mate Ferkića iz Krka, Rad JAZU, br. 164.

Poppi, Antonio. 2001. Ricerche sulla teologia e la scienza nella Scuola padovana del Cinque e Seicento (Soveria Mannelli: Rubbettino).

Schiffler, Ljerka. 1995. »Matija Frkić tumač i kritičar Tassa: Osservationi sopra il goffredo del signor Tourquato Tasso«, Prilozi za istraživanje hrvatske filozofske baštine 21/1-2(41-42), pp. 83-108.

Schiffler, Ljerka. 2010. Matthaeus Ferchius Veglensis, Mattheo Ferchio Veglense, Matja Frkić Krčanin 1583 - 1669 (Krk - Rijeka: Krčki zbornik - Verba d. o. o.).

\section{Matija Frkić on the Intellect and Immortality of the Soul}

\section{Summary}

At the center of this article is Frkić's understanding of the intellect and immortality of the soul. He writes about it in his work Vestigationes peripateticae de quibusdam philosophicis ad mentem Aristotelis (Peripatetic Researches on Some Philosophical Problems in the Spirit of Aristotle) published in 1639 in Padua. The initial position that can be traced throughout the whole argumentation performed by Frkic is as follows: Frkić is aware that in Aristotle's texts there is no concrete place on the basis 
of which it can be stated that Aristotle himself considers the soul immortal, therefore it is necessary to carry out an interpretation of the entire opus of Aristotle that would allow the possibility of the immortality of one part of the soul. In the second book of the Sixth Research of Peripatetic Researches, Frkic deals with the problem of the rational soul. He, according to Christian doctrine, holds that the human rational soul is immortal. It is also called reason or spirit and is separable from the body. Its action does not depend on the body; therefore, it can survive on its own.

Key words: Matija Frkić, immortality of the soul, intellect, peripatetic philosophy 